\title{
Intersections of gender and minority status Perspectives from Finnish Jewish women
}

\author{
Elina VuOLA
}

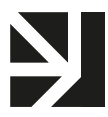

VERTAISARVIOITU

KOLLEGIALT GRANSKAD

PEER-REVIEWED

www.tsv.fi/tunnus

DOI: https://doi.org/10.30752/nj.77270

Aвstract - In this article, I examine how contemporary Finnish Jewish women understand their roles and identities as women in a small Orthodox Jewish community, on the one hand, and as members of a tiny minority in largely secular and predominantly Lutheran/Christian Finland, on the other. How do Finnish Jewish women negotiate their identities in relation to their community, strongly organised along gender lines, and in relation to Finnish society and especially its equality ideals and norms? I divide my article into four sections. First, I give a short overview of the theory of intersectionality, concentrating on its possibilities and limitations for the study of religion and gender in general, and for the study of Judaism, specifically. Second, I focus on my informants' views of the gendered practices of their Orthodox Jewish community, which, by many standards, is a very specific form of Orthodoxy, which could be called 'Finnish Orthodoxy'. Third, I analyse my informants' views on how they perceive being Jewish women in contemporary Finland. ${ }^{1}$ The intersection of the last two broad themes will highlight the realities of Finnish Jewish women in contemporary Finland. Fourth, I discuss possibilities and limitations of intersectional theorising in the light of my data.

\section{Intersectionality, religion and gender}

For some time, I have been interested in creating a more theoretical dialogue between gender studies and the study of religion, including theology. The need for it stems from the fact that religion, religious women and religious feminism are too easily omitted from the narratives of feminist theorising and historiographies of gender studies. I have been particularly interested in intersectionality since as a theoretical tool it opens possibilities for religion to be included more substantially in gender theories. At the same time, I have been critical of the ways this has

1 The importance of family and motherhood came up in most interviews, but for the sake of this article, I will concentrate on the two above-mentioned themes and write about motherhood in forthcoming articles. not really happened. As constructive alternatives, I have presented examples of how intersectionality and religison could be analysed together from the perspectives of gender research in theology and religious studies. Until now, I have done this in the context of Christianity (Vuola 20I2, 20I 5, 20I6, 20I7). In this article, I expand intersectionality as a tool to understand the interplay of religion and gender to the study of Judaism.

Intersectionality is not a unified theory or approach. It is not a grand new theory, but rather one way of conceptualising a central theoretical development in recent feminist theory. There are different ways of understanding and using the concept of intersectionality as well as various ways of understanding and naming the object of intersectional analysis: it can be asymmetries of power structure, identity (formation), difference and social 
division (Lykke 2003: 48 and 2005; Nash 2008; Yuval-Davis 2006). Sometimes these differences are related to disciplinary differences, such as philosophy and sociology, resulting in differences of focus. What all the approaches have in common is the analysis of differences such as ethnicity, race and gender, understood not only as forms of identity but as categories penetrated by social, cultural and political power.

Through intersectionality, a process of diversification of central concepts such as gender, women and the inclusion of differences between women has happened through the inclusion of race, class, ethnicity and sexual orientation in feminist theory. Intersectionality is a broad way of theorising gender in relation to these other differences and constructions of identity and selfhood, showing how a variety of oppressive structures such as sexism and racism - influence these. Religion has rarely been mentioned among these differences, and even less so as an empowering factor in spite of the insistence of religious feminists from different parts of the world.

As I have pointed out (Vuola 2017), most theorists of intersectionality do not even mention religion (besides Crenshaw I989, and other widely quoted scholars such as Davis 2008; Ludvig 2006; Lykke 2005; McCall 2005; Nash 2008). Several other gender scholars of religion have also pointed out this omission (e.g. Braude 2004; Castelli 200 I: 4-5; Mahmood 2005: I). Those scholars who do mention religion, even if on a rather general level, as one 'difference' or 'category' to be considered tend to be those who think within post-colonial feminism (e.g. Brah and Phoenix 2004: 83; Yuval-Davis 2006: 205).

My argument, which can be sustained through historical records, is that what is called intersectionality, since Kimberlé Crenshaw (1989) coined the term, has been explicitly present in feminist theology since the early i 970 s (see detailed argument, Vuola 20I7). Feminist theology - an umbrella term for many early feminist initiatives in different religious contexts, especially in the United States - has been and is inter-religious, ecumenical and global. The ecumenical and inter-faith organisations offered a concrete network of collaboration and mutual critique among feminist theologians from different parts of the world in the r96os and r970s (Vuola 2016: 316). Interestingly, for the sake of this article, the feminist theologian Rosemary Radford Ruether took different forms of oppression as her explicit starting point already in the I 970 . In addition to sexism and racism, Christian antisemitism and ecological issues have since been the focus of her work. In her books and articles, she analyses gender, class issues, racism, colonialism, antisemitism and environmental destruction as interconnected forms of oppression and marginalisation (Ruether I 972, I 982: 52-4).

Other early feminist theologians shared Ruether's understanding. For example, in one of the very first collections of feminist theology from $1979,{ }^{2}$ the editors, Carol Christ and Judith Plaskow, write: 'this dualistic pattern has been adapted to the oppression of other groups, including Jews and blacks, who, like women, are seen as more carnal and irrational than the dominant men' (Christ and Plaskow I979: 5). It is noteworthy that this collection, probably the very first in feminist theology, includes articles by Christian and Jewish, and post-Christian and post-Jewish theologians. Besides the academy, the ecumenical and inter-faith contexts have been significant for various forms of feminist interpretations of religion. Within these,

2 A European volume of feminist theology came out the same year. See Halkes and Buddingh ( 1979 ). 
the trans-national ecumenical dialogue of women from Christian churches expanded to dialogues between feminists from different religious traditions (see, for example, Egnell 2006; Eck and Jain I986; for newer Jewish feminist theological research, see, for example, Lahav 201 5; Raphael 2003).

\section{Intersectionality, feminist theology and Judaism}

The inclusion of gender (women, feminist approaches) in the study of religion in the r 970 s was - and is - called feminist theology. Although it has been largely a Christian enterprise, the early feminist theological work included Jewish scholars. They often called their work Jewish feminist theology. However, the large body of work on women and/or gender in Judaism should not be reduced to this. Calling it theology is problematic, because of the nature of the work, but the term may also hide the specific nature of Jewish gender studies, which includes ethnographic research, textual analyses (Torah, Talmud), the study of halakhah, research on women in the history of Judaism, gendered practices and teachings, Jewish masculinity studies, and so on (on the variety of Jewish gender studies, see, for example, Adler r 998; Baskin I998, 2015; Biale r995; Fader 2009; Goldstein 2009; Greenspahn 2009; Hartman 2007; Heschel I983; Labovitz 20 I i NeriyaBen Shahar 2018; Peskowitz and Levitt I997; Plaskow I990; Raphael 2003; Ross 2004; Sztokman 20II). Probably the most correct term to use for this extensive and growing body of work is Jewish gender studies or gender studies in Judaism, which can include specifically theological work, whether one calls it feminist theology or not. ${ }^{3}$

3 Because of this broad variety and the interdisciplinarity of research on Judaism today,
Intersectionality as a theoretical framework has been used in some recent publications on gender and Judaism (in the Nordic context, see Dahl and Thor Tureby 2009; Nylund Skog 2008; internationally, see, for example, Brettschneider 2017; Greenebaum I999; ${ }^{4}$ Morgenshtern and Pollack 2016). In most of these studies, religion is not counted as an intersectional 'difference' or category. Judaism and Jewishness are theorised almost exclusively at the intersections of class, gender and ethnicity. Even when religion is explicitly mentioned as an intersectional category (Dahl and Thor Tureby), Judaism as religion is not analysed intersectionally. Maria Brettschneider's book addresses the absence of Jewish subjects in intersectionality studies, arguing that even though Jewish feminism is a phenomenon reflective of intersectional identification through the categories of gender, sexuality, ethnicity and religion, it has not dealt with race. Maria Morgenshtern and Shoshana Pollack use intersectional theory in their research with Jewish immigrants to Canada from the former Soviet Union, but do not discuss either religion or gender. Their interest is in expanding intersectional analysis to white, educated immigrant 'others'. A similar interest is found in Susanne Nylund Skog's article (2008), in which she analyses Jewishness in the context of critical whiteness studies.

the very term Jewish studies is debated. Some have even asserted that Jewish studies is as old as Judaism itself, because internal scholarly production is evident in the biblical corpus and throughout Jewish history (Bell 201 5: I).

4 Greenebaum's article appears in a special issue of the journal Race, Gender and Class focusing entirely on the Jewish American context. Her article pays critical attention to the resistance to include Jewish women and their 'difference' in intersectional discourses. 
In other words, a critical reconstruction and deconstruction of religion through an intersectional analysis is not carried out in any of these studies, in which intersectionality covers the common categories of race, gender and ethnicity in the context of Judaism. This is understandable when Judaism is understood primarily in terms of ethnicity and culture. It may also be reflective of disciplinary differences. The interest and focus of feminist theologians and other gender scholars of religion is, obviously, in religion: the perspectives of gender, race, class and ethnicity are brought into the analysis of religion. Scholars in other fields, including gender studies, may take religion into account as one possible intersectional category (even when this is not common), but religion qua religion is often left intact. This happens in spite of the existence of Jewish feminist theology, which - like its Christian counterpart - directs its attention to the androcentrism and sexism of the central teachings of Judaism.

Hagar Lahav makes a similar point about Jewish feminist theology. Also in the context of Jewish gender studies, the theological work is often set aside or not paid enough attention. She simultaneously affirms the view that Judaism is not only a religion, but also ethnicity and culture (Lahav 2015: 357) and that Jewish (feminist) theology should be used as a tool of analysis (ibid. 363). She quotes the prominent Jewish feminist theologian Judith Plaskow when saying that 'theology is largely situated at the fringes of Jewish feminist discourse both within and outside Israel. The discourse accords much concern to practices, the status of women in various institutions, and critical analysis of texts, but not to theology.' Plaskow's work, like that of her Christian colleagues, was aimed at the transformation of (Jewish, Christian) religion.

As I have argued elsewhere (Vuola 2017), the idea of intersectionality was present in feminist theology since its beginning, even when it was called something else. Thus, it is not a product of 'secular' feminist theory, but it has a history within the study of religion, although this is not acknowledged in the historiography of feminist thought. While early feminist theology was predominantly Christian, it is important to note the presence of research into other religious traditions. These include Judaism.

Especially when the focus is on gender, intersectionality may function as a theoretical tool to understand the interaction - between belonging to the Jewish people, culture, and religion - in the study of diaspora minority Jewish communities. There is a variety of Judaisms as they are lived historically and contemporarily in different cultural contexts. The Finnish Jewish community is unique in many ways, not least when analysed from a gender perspective. Naming the sense of belonging to the Jewish people 'ethnicity' is, according to my understanding, not correct in spite of belonging and ethnicity overlapping to some extent. Also, the small Finnish Jewish community is multi-ethnic, as people come from a variety of cultural backgrounds. ${ }^{5}$

Religion could be counted as one of the differences or categories in intersectional analyses. As is the case in the more usual categories - class, race, ethnicity - religion, too, is often inseparable from one's identity formation and social position. In many contexts, it is difficult - if not impossible - to 'separate' religion from one's understanding

5 There are only a few ethnographic studies on the Finnish Jewish community. Besides my own project, there are three unpublished MA theses (Czimbalmos 20I6; Larsson 2014; Shaul 2017), which are based on interviews, and the recently started ongoing research project 'Boundaries of Jewish Identities in Contemporary Finland', in which ethnographic interviews will be one source of information. 
of oneself, individually, socially and culturally. This is especially clear in those cases where people have some kind of attachment to their religious tradition, which can include a critical and questioning attitude to it. As in the case of race or ethnicity, the relationship to one's religion is contested, multi-faceted and evolving. In all these categories, the relationship is both about embodied and holistic ways of being oneself in a given society at a given time, and about the discrimination, marginalisation and stereotypisation one faces on the basis of race, ethnicity and gender. Thus, one's multi-layered identity as a Jew also includes the history and contemporary experiences of antisemitism even when religion does not play a central role in one's Jewish self-identification.

Furthermore, if religion is considered as a difference, as an important social division and producer of power asymmetries, which the concept of intersectionality aims to theorise, it is crucial to understand religion in terms of both power (religious institutions, laws, elites, moral codes, etc.) and as part of one's identity, also positively, for both women and men. Religion, together with gender, ethnicity, class and so on, can thus help us to understand the inter-structuring of all these aspects, which can be explained in terms of identity or power struggle.

It is crucial that scholars of religion pay attention to sexist interpretations and practices within religions, but this should be done in relation to women's religious agency. In intersectional analyses, religion could thus be seen both as a 'difference' between women of different cultures and religions but also within a given religious tradition and society and as a gendered critique of religion. This makes it possible to understand religion both as a structure of power and as a source of empowerment and positive identity. Religion as an intersectional category is not merely a reflection of the secular, but operates according to its own logic too; gender asymmetries legitimised by religion are analysed also - and possibly primarily - within different religious traditions.

The interplay of continuity and change characterise all religious traditions, and especially the monotheistic religions of the book: how to interpret the tradition and the foundational texts in different times and contexts and at the same time be rooted in the tradition? This question is central in issues of gender and sexuality. Finnish Jewish women negotiate with religious laws and practices as modern, often secular, minority women in a society in which gender equality is often presented as the yardstick of modernity.

Since Judaism cannot be defined only through or as religion (see, for example, Dencik I993; Lahav 2015: 357) but also as a sense of belonging to a people - which includes customs, history and traditions, experiences and values - intersectionality may be one fruitful way to understand how these elements come together in the lived experiences of contemporary Jewish women in a specific context, namely the largely Christian Finland.

As a scholar of religion, my interest is, among other issues, in my informants' views on Judaism as religion, even when Judaism is not reduced to it (by me or by them). Thus, in this article, I use intersectionality as a way to analyse religion too. A conscious look at the intersection of gender and religion reveals, on the one hand, that religion should be analysed from the perspective of gender, and gender from the perspective from religion, on the other. In other words, I consider religion as an intersectional category in relation to other categories but I also go further by extending an intersectional analysis of religion. ${ }^{6}$

6 I hope to be able to write more about the theological elements in my data as well as 


\section{Interviews with Finnish Jewish women}

In 2015-16, together with Dóra Pataricza, I interviewed fifty Finnish Jewish women in Helsinki and Turku, where the two Finnish Jewish communities are located. ${ }^{7}$ The women interviewed were born between 1928 and I997, most of them between the r940s and I970s. Thus, most of the interviewees were middle-aged at the time of the interview. Twenty per cent of the interviewees had their origin outside Finland but all had lived there for several years. Twenty-eight per cent of the informants had converted to Judaism at some point in their lives, most of them because of marriage with a Jewish man. I leave out the converts as well as those who had lived in Finland less than ten years, but include those who had gone through the child giur, a

to analyse the interviews theologically, with the help of Jewish feminist theologians. For the sake of this article, I present my more general argument about the importance of not just religion but also feminist theology in intersectional gender studies. So far, I have done this in the context of Christianity.

7 The research was realised as part of the project 'Embodied Religion: Changing Meanings of Body and Gender in Contemporary Forms of Religious Identity in Finland', funded by the Academy of Finland and directed by myself (2013-I 7 ), in which we studied certain religious minorities in Finland, especially from the perspective of gender and minority status. The project questioned such approaches to religion, and especially to religious women, that are either culturally obtuse (seeing secularisation as inevitable and natural) or openly negative (seeing people, particularly women, as victims). By taking religious people's agency as a starting point, the project highlighted the dynamics between continuity and change within religious traditions. I warmly thank all the women who shared their thoughts with me, as well as the Jewish communities of Helsinki and Turku for their trust and practical support. specific Finnish practice mostly for children whose father is Jewish and the non-Jewish mother has not converted; these interviewees had a lifelong experience of Jewish life, family and identity from their father's side. With these restrictions, my final data for this article consists of thirty-eight interviews. ${ }^{8}$

The names and exact ages of the informants have been changed. With regard to age, I have grouped the informants in three generations: the oldest generation (those born in the r 920 and r93os), the middle generation (born between the r 940s and I 970s) and the young generation (born in the r 980 s and I990s) in order to secure their anonymity in the small community. When citing my informants, I will refer to them by pseudonyms and generations. All the translations from Finnish into English are mine.

The initial call for interviews was made through the Helsinki Jewish community's journal and membership list. However, most potential interviewees were approached by Pataricza or myself directly, in order to have a representative sample with respect to age and other factors, as well as to cover also the Turku community. Most interviews were roughly an hour long, some shorter, some longer. ${ }^{9}$ The interviews were based on a semistructured model, according to which there was a list of questions that were followed, but the interviewees significantly influenced both the process and the content of the interviews. Thus, there are differences between the topics

8 Conversion is a complex process, and especially so in the case of Judaism. Understanding the Jewish identities of those women who have converted as adults would demand an analysis of its own. I hope to do this in the future.

9 All interviewees signed a consent prior to the interview. The interviews were recorded and transcribed, and they will be placed at the Finnish Social Science Data Archive in Tampere. 


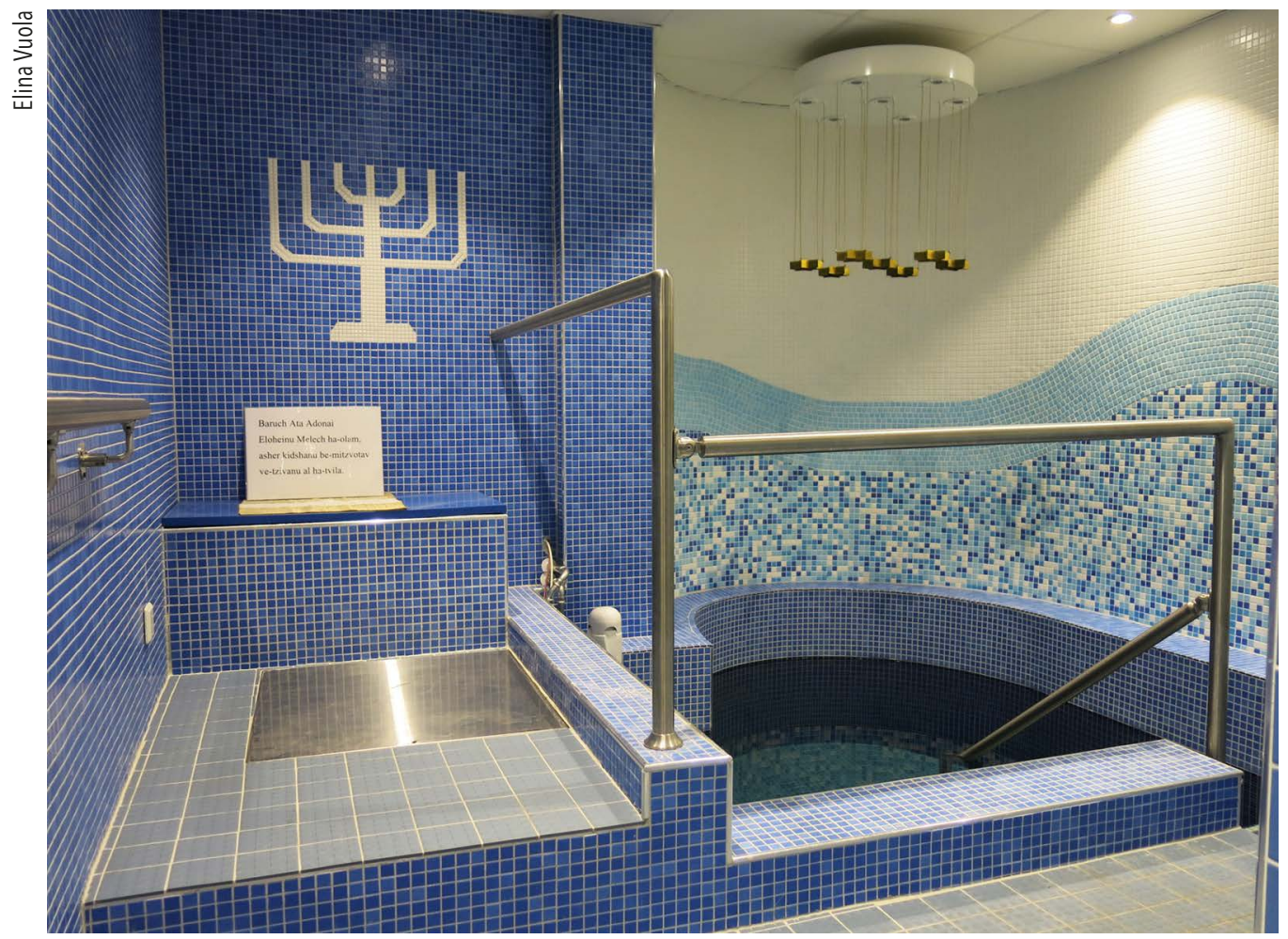

The new mikveh of the Helsinki community.

covered and the extent the women shared their personal histories.

The most important themes in the predesigned set of questions included the following: What is your religious/Jewish background and your relationship to Judaism (family background, possible conversion, Jewish/non-Jewish marriage, children raised Jewish or not)? How would you describe your Jewish identity? What kind of Jewish upbringing (family, school, community) do you have? Do you bring up your own children Jewish and what does it include? On a more gender-focused level, the questions included: How would you describe what it means to be a Jewish woman (this included sometimes, but not always, direct questions about the use of mikveh, purity regulations, women's mitzvot, etc.)? What is your relationship to the Jewish community? And to its gendered practices?
How would you describe women's position in the Finnish Jewish community? Further questions involved experiences of minority status in Finland and possible experiences of antisemitism as well as changes in these areas during the interviewee's lifetime. Thus, the entire set of interviews was based on an intersectional understanding of the interplay of gender, age, ethnicity, national identity and religion. However, because of the richness of the interviews, it is possible to analyse them from a variety of theoretical perspectives, intersectionality - which I do here - being one of them. ${ }^{10}$

10 In a forthcoming volume (in Finnish), which includes articles by the research team and its different empirical case studies, I analyse my data on the Finnish Jewish women from the perspective of lived religion. 


\section{Women's perceptions of the Jewish community}

The first broad theme by which I will analyse my data is my informants' views of the gendered practices of their Orthodox Jewish community. This issue was at the heart of the research: as mentioned, one of my main interests was how women perceive their community, including in religious terms. How do they negotiate with the gendered structures, practices and teachings of the community? They could approach this question from any angle and frame it as they found proper: some talked about gender equality, some did not.

The self-understanding of the Finnish Jewish community is Modern Orthodoxy, which means a sometimes difficult balance between the commitment to the observance of the halakhah, the Jewish law, and a secular, modern life. Even though Finnish Jews have always understood their community as Orthodox, they have also integrated fully into Finnish society. In practical terms, this means that the ritual space and much of the community life are organised according to Orthodox rules, but in every other respect the members live like any other Finns - with some differences such as Jewish holidays and dietary rules. Thus, Orthodoxy is mostly restricted to the ritual setting (synagogue) but otherwise the vast majority of Finnish Jews find it practically impossible to live an Orthodox Jewish life in Finland. There is thus a kind of continuum of Orthodox Judaism, in which some are closer to the standard understanding of what Orthodox Judaism consists of, some do not even seek it, and most accede to having an Orthodox ritual space and a non-Orthodox, but nevertheless Jewish, life outside the synagogue.

Gender issues are at the heart of any definition of a community's level of Orthodoxy. Internationally, the role of women in
Orthodox Judaism constitutes one of the most important distinctions among contemporary Modern Orthodox and Haredi Jews. Modern Orthodox women believe that enhancing their religious knowledge and status are permissible according to the halakhah (see, for example, Berman 200I; Taubes 2018).

Most of the women interviewed did not disagree with having men's and women's sections in the synagogue. Most of them did not feel excluded or undervalued as women. There were those who did, however, which reflects the variety of opinions in the community from a gender perspective. By and large, Finnish Jewish women live like any Finnish woman: educated, equal in many ways, working outside the home, a spouse and mother. Being a Finnish Jewish woman was often positively mentioned by those informants who had been able to compare with different forms of female Jewish life internationally.

Many women emphasised how Judaism is a woman-friendly religion and tradition, and sexist rulings are rather a result of power issues. For example, Beth of the middle generation commented:

[Changes] are not possible in Finland, because we have such men's power here that they think that the community in Helsinki should not have a female chairperson; it is difficult to imagine, even though it was possible in Turku. ${ }^{11}[\ldots]$ Judaism is in principle more equal than any other religion. [...] It is a religion where all Jews, men and women, can approach God directly. All the other religions have some kind of mediator - Jesus in Christianity, Mohammed in Islam. They are male role models. In Judaism, we do not need these

11 The spokesperson of the Jewish Community of Turku was for a long time a woman, Ruth Hasan. 
mediators. Every woman and man can approach God directly. And God has no figure. God is spirit, Shekinah.

Beth stressed her spirituality and faith although she considered herself a rather secular Jew. She said she even thought of becoming a rabbi, when she was young. Beth was one of the interviewees who had studied Jewish women's (feminist) theology. On this basis, she was of the opinion that women's (restricted) role is not halakhic but rather a result of society and community, ruled by men until very recently.

Anita of the middle generation was also very critical of male power in the community:

Well, it always seems to be men in the positions of power in the community. But women are involved, and they do a lot of things, but it's all men in power, in positions of power. Who, what woman has a position of power there? Absolutely none.

She, too, was quite learned in Judaism.

Well, I don't agree with some of these basic prescripts of Orthodox Judaism, because of the gender disparity. [...] I have studied Judaism in different places in great depth, Orthodox Judaism and the history of Judaism. [...] What I might have got is a small kernel as a child, but I have educated myself. I see a lot that I really respect and appreciate about Orthodoxy, but I have issues with the gender disparity.

EV: And what is the main problem for you?

Anita: Lack of choice in religious participation. [...] I am not interested in becoming a rabbi, but I think that there are women who have a deep spiritual longing to have a deeper, more complete role in the religious life.

Anita is among those women who expressed an interest in women's religious education. Some expressed the need for greater opportunities for women to develop a knowledge of their religion and to deepen their spirituality - something that would be totally possible even in an Orthodox setting. There have been intentions of forming women's study groups. This was considered important by very different kinds of women, but was accentuated among the converts. Depending on one's background, there is a great variety in Finnish women's knowledge of Judaism, texts and practices. It is important to note that this wish for a women's study group was expressed as an interest in learning more about one's religion: the Torah, Talmud, the halakbah, other texts and teachings, and the intellectual heritage of Judaism as religion. This is noteworthy, because most interviewees did not define Judaism primarily as religion or themselves as religious.

Bat mitzvah for girls was introduced in the mid-seventies, and it was considered a positive development by the interviewees. Older women who did not experience it approved the development, in spite of girls' bat mitzvah not being identical in the amount of education and ritual importance with boys' bar mitzvah.

Similarly, the construction of a new, beautiful mikveh in the Helsinki community some years ago was considered important by the informants, even though most Finnish Jewish women do not use it. When there were critical views, they were mainly about the money spent on its construction. For example, Chana of the middle generation said: 
I have seen the new mikveh, it is really beautiful. I have not been in it, though. [...] It is difficult to know how many women use it. [...] There were problems only because of the amount of money spent. Otherwise not, because a community must have a mikveh - it is part of Judaism.

[...] I have been in mikveh before my wedding, and after that I have not.

Chana believes it is especially the converted and some originally non-Finnish women who use the mikveh. The growth in its use is a result of growing immigration and conversion for religious, not family, reasons. She, too, states how in her circle of friends, from the old Finnish Jewish families, nobody uses the mikveh - this in spite of her insistence on its importance for Judaism and Jewish life.

Also Anita simultaneously affirms the importance of the mikveh for Judaism in general and her personal lack of observance:

I really support the mikveh. Even though it has never been a part of my life, I recognise the extreme importance and value of the mikveh for the community, and I agree with the idea that this was rebuilt. [...] This is a basic tenet of Orthodox Judaism, and this is an Orthodox community: there has to be a kosher mikveh, has to be. And it also serves so many important roles in terms of the community, and the ritual within the community. I think it's really important. [...] It is not something that I follow, but I have been to mikveh on more than one occasion.

That the mikveh has not been and is not part of (most) Finnish Jewish female life is an important sign of tension between the Orthodoxy of the community and the de facto lifestyle and lived Judaism of Finnish Jews. In Turku, the old mikveh was used as a storage space for car tyres, and the women interviewed there said that they did not even remember their mothers and grandmothers ever using it. The observance of niddah (separation due to ritual impurity) has thus, among Finnish Jewish women, died out a long time ago - if it was ever even a reality, which is difficult to know. If middle-aged women said their mothers and grandmothers did not use it or teach its use to their daughters, it most probably means that the practice was never really observed among Finnish Jewish women - even those considered very traditional and pious by other standards.

One reason why the Orthodox gendered practices, such as the gender separation in the synagogue, were accepted and endorsed was the small size of the community and the possibility of keeping it open to all kinds of Jews, including the most observant ones. Maintaining Orthodox standards, even when not followed by most beyond the synagogue, makes it possible for everybody to participate and be included. One's own wishes or standards were thus not the yardstick for greater equality but rather the survival of the community. Even those women who were willing to get rid of the separate seating did not really push for it.

In several interviews, however, criticism was expressed of practices considered outdated or meaningless, such as the purity laws or the introduction of a mechitza (a curtain separating men and women) in the prayerroom as well as of patriarchal attitudes and hierarchical structures. Especially the recent mechitza in the downstairs prayer-room raised open criticism. This was the norm among the interviewees dealt with here-Jews by birth - but also among converts. Women's critical evaluation of some important genderbased differentiations in the community were thus shared by both groups, even though to a much lesser degree among the converts. 


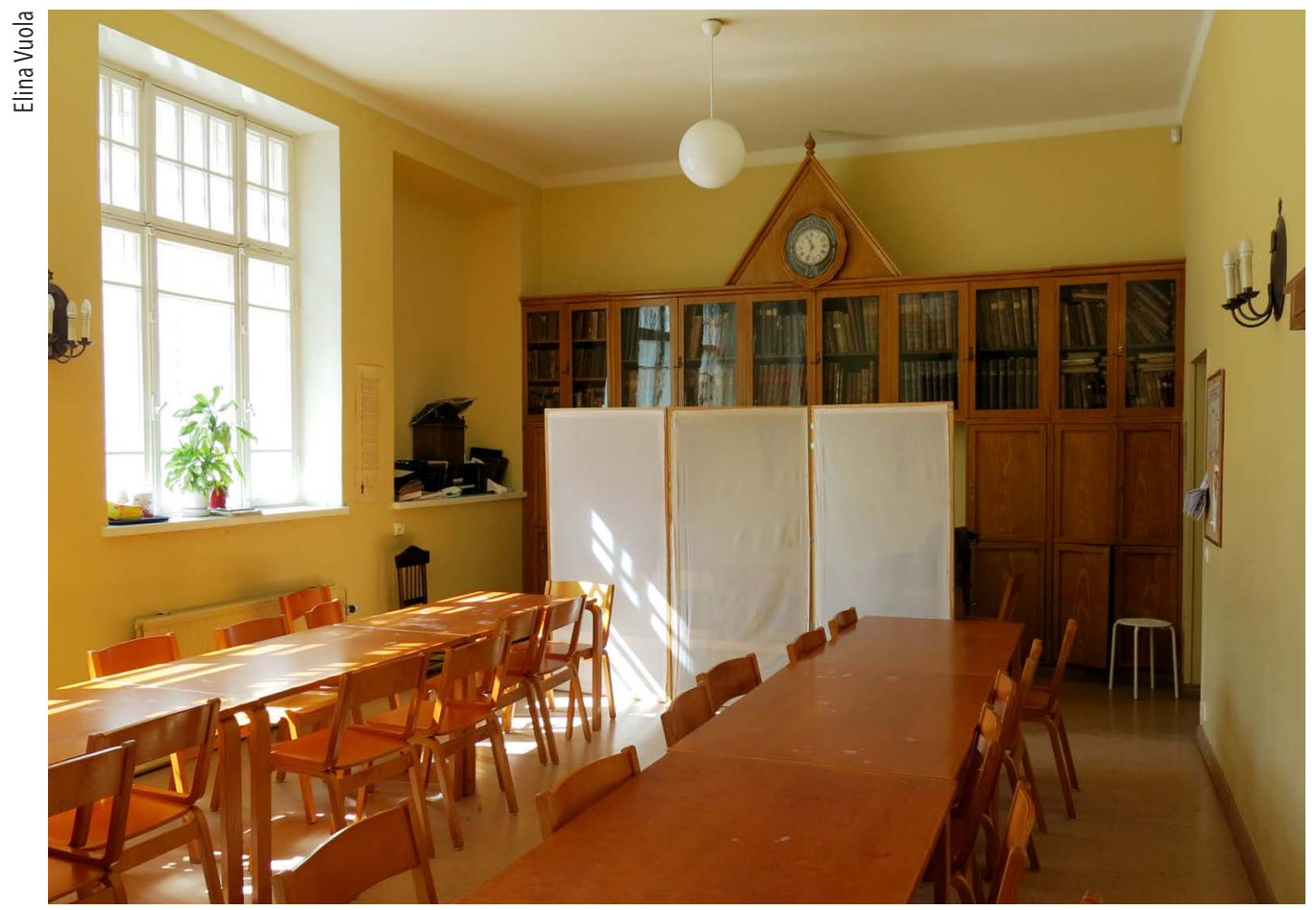

The mechitza in the prayer room at the Helsinki community.

Conversion to Orthodox Judaism lessened but did not eliminate gender-based criticism.

All the women who mentioned the mechitza (a velvet curtain) in the minyan ${ }^{12}$ room were critical of it. They represented different ages and backgrounds, but none of them felt positive about it - in spite of the fact that almost nobody among our interviewees questioned the separation of men and women in the synagogue where women sit in the balcony area and men are downstairs. The interviewees were wondering when and why the mechitza was introduced, because it had not always been there. A man in a responsible position in the community said that it had been introduced as late as the late r 99os, when some women started to want to attend

12 The quorum of ten Jewish adults required for certain religious obligations, which in Orthodox Judaism includes only men. prayers on Fridays. There were women among those interviewed who said they would like to attend on Fridays, but the single most important reason for why they chose not to participate was the mechitza. It was described as uncomfortable because the small space behind it made women feel trapped. This is no surprise, since the mechitza, when mounted, really leaves only a few square metres in the back of the room for women to stand in. The mechitza is made of somewhat transparent material, which makes it possible (but difficult) for women to see - but at the same time, it does not render women totally invisible, which puts into question the whole motivation for its introduction.

According to younger-generation Dania,

It [the mechitza] really bothers me. [...] I know that according to Orthodox belief, a man should not be distracted when 
praying. [...] But I have to say that it [the mechitza] is one reason why I don't come to pray on Fridays, because I just can't stand it. [...] It is ridiculous, I think it is totally ridiculous.

Also in Turku, some women commented on the mechitza in their 'small shul' downstairs in the community building. They expressed similar opinions to the women in Helsinki: it was considered no problem that women and men do not sit together in the synagogue, but women felt discomfort in the small space behind the curtain. The women in Turku expressed their sentiments as bluntly as the women in Helsinki:

I don't like to be in the little shul. There are a handful of women, and then some curtain is drawn in front of them. [...] If I put it in one word, that is stupid. We are an Orthodox community, but really we aren't any more. [...] I think we could be much more open nowadays in these issues.

(Gabi, middle generation)

Interviewees in Turku believed that more women would attend if services were held only in the upstairs synagogue, not in the minyan room. It was the rule in Turku because of the old age of the members, who had difficulties in getting upstairs by the stairs. For example, Gabi was of the opinion that more women would attend if the mechitza were removed or if the prayers were held in the synagogue where women have more physical freedom and space and do not feel shut out. Thus, it is not the gender separation in itself which offends women, but the very concrete practice of shutting them out, which made them feel not only uncomfortable but also humiliated and excluded.

\section{Being a Jewish woman in contemporary Finland}

For my informants, Finnishness and Jewishness are inseparable - overlapping but not identical. Belonging to a minority defines one's Finnishness even when one's national identity is clear: 'I am a Finnish woman who has a Jewish religion' as Rachel (middle generation) states. The problematisation of one's Finnishness and Jewishness - or the possible opposition of the two - do not usually stem from oneself but from the surrounding society. My informants did not call it antisemitism, of which they did have some experience, but it was understood as the result of the invisiblity of Judaism in Finland and the low level of knowledge shown by Finns about it.

I have been asked 'are you a Finn or a Jew?' Well, I said that I am very much a Finn [sighs and becomes emotional] but in the end I am a Jew. [...] It is very difficult for an average Finn to understand that $I$ am as much a Finn as one can be. But I am Jewish. [...] There are so many ways to be a Jew. I confess I am very traditional. But I am not so religious. [...] The truth is that we are assimilated traditional Jews.

(Leah, middle generation)

The difficulty of explaining - and even putting in words - this intersection of Finnish (national) and Jewish (ethnic, cultural, religious) identities to outsiders reflects the overlapping and intertwined aspects of one's identity, which all theories of intersectionality aim to describe. In the lived experience, it is impossible to prioritise one category over the other (is one first a Jew, and then a Finn, etc.), even when this may be the expectation of other people.

Judith, too, identifies herself as both a Finn and a Jew, inseparably. At the same time, 
her Finnishness is coloured by the Jewish experience:

The legacy from home has been so strong that I never had to question my identity. So that if someone asks me what am I more, a Finn or a Jew, it is difficult to answer, because I am both. But the older I become, the more I experience being some kind of outsider in this culture. That I always have had the experience of not being exactly the same as others. That I cannot identify myself fully, even though I am really Finnish, and many aspects of Finnishness are familiar and dear to me. $[\ldots]$ In that sense, Judaism is interesting, because it is not just a religion and not just a culture $[. .$.$] it is difficult to put in words$ or explain [laughs]. [...] Well, for example, all my life I have heard about the Nazis and the concentration camps and I have been conscious of that tragedy affecting also my extended family. But I have always thought about it, you know, rationally: like, OK, this has happened, and I can tell that my grandfather faced this and that. I have seen movies and I have cried, but it has been more compassion for someone else. But now, for the first time, it has happened that [...] when a few years ago I visited that [Holocaust] memorial in Berlin [...] I sort of physically collapsed. Even now I get this feeling [becomes emotional] of a connection to my own history, emotionally, that it is not just what has happened to others but it has happened also to me. That I carry that history myself. And that, me too - it could [have happened to me].

(Judith, middle generation)

Even though there was no Holocaust in Finland in the same sense as in Central Europe, many Finnish Jewish families have more distant relatives who were directly affected by it. The absence of Holocaust has meant a continuation of generations and traditions among Finnish Jews: many informants talked fondly of their grandparents and how these taught them Jewish traditions - an intergenerational link that was destroyed in Central and Eastern Europe. ${ }^{13}$

Most of my informants did not express any conflict or tension between the gender equality ideals of Finnish society and their Jewishness. In fact, Finnishness as a crucial part of one's identity was often positively linked to the position of women: the opportunity to educate oneself, to combine work and family, and to have an equal share of duties in the family context. Some said that their Finnishness is positively accentuated in international Jewish contexts: they feel, as Jewish women, that the high level of equality in Finnish society is something exceptional and important. They are used to it and they embrace it, also as Jewish women.

Since most Finnish Jewish women live in mixed marriages, one interesting issue that came up in several interviews was the role of the non-Jewish husband, which we started to call the 'tolerant Finnish man'. He allows his children to be raised Jewish, attend the Jewish kindergarten and school, and his sons to be circumcised. He celebrates Sabbath and Jewish holidays at his home and may follow Jewish dietary laws even if the home is not fully kosher - all this without converting to Judaism. According to many informants, their non-Jewish husbands respect and support their wife's Jewishness. In that sense, mixed marriage was not experienced as a problem by my informants, who said that as mothers they are able to raise their children Jewish.

As was said above, many interviewees stated how little Finns know about Judaism. This ignorance can be revealed as curiosity 13 I thank Dóra Pataricza for this observation. 
but also as stereotypes. One can live in peace in Finland, and Finnish society is respected, but according to several informants, the situation has been changing for the worse.

Open antisemitism is pervasive and growing in Europe. In December 2018, in a report by the European Union Agency for Fundamental Rights, thousands of European Jews related that they had experienced a physical, antisemitic attack in the past year, while 28 per cent said they had been harassed. The survey was carried out in twelve EU member states where most of European Jews live (FRA 2018). Finland was not included, but Sweden has seen one of the sharpest rises of antisemitism. One of the informants, younger-generation Jael, who had lived in Sweden, said that it was more difficult to be a Jew in Sweden. She linked this to a greater respect for minorities and their right to preserve their identity in Finland. According to her, there is more pressure to assimilate and integrate in Sweden, and secularism or even atheism is the norm. Obviously, she was not just a Jew but also a Finn, thus experiencing the pressure doubly.

There is lack of information about current antisemitism in Finland, but my informants' views were consistent with the EU report: the situation has become worse in a very short time span. The insecurity and fear are real even when Finnish Jews have not experienced a violent attack. The small size of a Jewish community does not protect its members from antisemitism - quite the contrary, it can possibly be the other way round. ${ }^{14}$

14 In a recent seminar on antisemitism and Islamophobia in Helsinki, Professor Rafal Pankowski (Security and Crisis Centre of European Jewish Congress) pointed out that the size of the community does not correspond with the hostility, taking his native Poland as an example. Poland is today one of the most monoethnic and
When thought of intersectionally, the growth of antisemitism means, among other things, that one's Jewishness becomes a source of experienced difference and otherness. An earlier positive minority identity becomes a source of fear and prejudice, causing Finnish Jews too to hide their Jewish identity and to be careful about who they talk with about it. The rapidly changed situation shows in antisemitic comments, threats against the Jewish community and the subsequent feeling of insecurity, as well as the fear of visibly wearing Jewish symbols such as Magen David (the Star of David).

For example, Judith says somewhat jokingly that it is a different thing to say that you come from Tampere from saying that you are a Jew', because

people know so little about Judaism, really. I have been sort of disappointed [laughs] that people don't know anything. [...] It has been a shock for me since I socialise with highly educated people. That they don't know, or know very little. [...] I believe there are many stereotypes, but I have not faced these much. If people know [that I am Jewish], they mostly avoid the subject, I think. There must be stereotypes [...] but, yes, very seldom. It is rather that people don't really care. They are not interested, they don't ask [laughs], it is a pity, because I would be happy if they were more interested. (Judith, middle generation)

Also Dania of the younger generation says that it is very easy to live as a Jew in Finland, but

least diverse societies in Europe, but levels of both antisemitism and Islamophobia are among the highest in Europe (Pankowski 2019). 
When these incidents in Europe - in Sweden and in Hungary - happened, I noticed that I stopped wearing my Magen David. I always had it, until about four years ago. When these attacks in Malmö and Copenhagen happened, I took it away.

EV: So you started to feel like you don't want to show it?

Dania: Yes, and it is really sad. In a way I feel that I am cheating myself for not wearing it, but [...] I am afraid of someone judging me because of it hanging around my neck.

In the EU survey, the media was named as the second-most important area of society (after the internet) where antisemitic comments are made. Many of my informants stated, for example, how they avoid talking about the situation in Israel with non-Jewish people. The public discussion of the IsraelPalestine conflict feeds antisemitism, they fear. It is considered contradictory, because

I'd rather not talk about the politics of Israel with Finns, because [...] I myself oppose many things but at least I try to figure out what the point in the conflict is. That it is not just because they are Jews. You have to be really informed to know why the conflict is there, what the reasons behind it are, and so on. (Rachel, middle generation)

Also the youngest interviewees referred to this - for example Susanna, who has been to Israel a few times:

EV: Have you ever experienced antisemitism?
Susanna: No, I haven't. The only thing is that when people want to talk about Israel, but I am not an Israeli. So, you are then like, 'I cannot really comment on that'.

EV: Is it then like when someone knows you are Jewish, they ask you about Israel?

Susanna: Yes. Not like right away, but they may sometimes ask 'so what do you think about it?' And I am like: 'Well ... there are idiots and there are normal people there.' I cannot say anything else [laughs]. It is annoying that Israel and the Jews are linked together right away, because I am not interested in what is going on there. [...] On the other hand, if things get really bad, I would be glad to be there [laughs].

There is, then, the unfortunate possibility that the growth of antisemitism in Europe will alter the long tradition of Finnish Jews feeling both safe and proud of being Finnish Jews.

\section{Possibilities and limitations of inter- sectionality}

In this article, I have aimed to apply the concept of intersectionality to the study of Judaism, and more specifically contemporary Finnish Jewish women. I argue that intersectionality may illuminate some aspects of Jewish diaspora identities, mainly because the surrounding cultural and societal context affects any Jewish experience so much. In the case of Finland, this is most clearly to be seen in issues related to gender.

Even when Judaism is not understood primarily as religion - something that most of my interviewees agreed with - the religious aspect cannot be arbitrarily cut off. Besides religion, an intersectional analysis includes aspects of belonging to the Jewish 
people, Jewish traditions and values. Thus, experiences of the minority status and growing antisemitism are important to take into account in the lived Jewish experience. All these overlap with gender.

There is lack of interaction between feminist theology - in all religious traditions - and women's lived religious experiences, self-identification and agency. This lack of interaction is true of most Jewish gender studies as well. In the future, a richer and more substantial dialogue between gender theories, Jewish gender studies, Jewish feminist theology and ethnographic research will be important.

As I argued at the beginning of this article, it is both important and possible to treat religion intersectionally as a 'difference' among women as well as to analyse religion as a cross-cutting element with other differences, identity categories and power asymmetries. However, it is imperative to distinguish between different aspects of religion - the institutional, cultural, ethical, doctrinal and spiritual - in order to avoid reducing any religious tradition to a single aspect. It is essential that scholars pay critical attention to sexist interpretations and practices within religions, but this should be made in relation to women's religious and other agency. This is exactly what I wanted to do when interviewing Finnish Jewish women.

There is no singular liberal-secular society above different historical, cultural, linguistic and religious contexts. No broad generalisations of Judaism (even Orthodox Judaism) should be made only on the basis of its gendered teachings. My data makes clear that even when gendered practices and teachings are criticised, the broader cultural context is a stronger factor in Finnish Jewish women's lived experience. The Finnish Jewish community is strongly shaped by the surrounding social and cultural context.
Attention to women's views of their religion makes clear that they do not necessarily follow the gendered practices or obligations of their religion. They often just ignore them. In the case of Judaism and my data, this is clearly shown in how ritual purity regulations (niddah), including the use of mikveh, have not been followed by most Finnish Jewish women in decades. It can be said that it has not been part of Finnish Jewish women's identity. As such, it reflects what I said above: that gendered religious teachings - even when considered imperative - should not be taken as the yardstick of women's lived experiences. Simply ignoring some obligations and not considering it a problem - even among the oldest generation - is more a result of the gender ideals of the surrounding society and culture than of a conscious feminist critique of one's religion.

Changes to a stricter direction in the community, such as the introduction of the mechitza in the prayer room of the Helsinki community, were by and large considered unnecessary and harmful. It was criticised especially by the more observant women (some of whom were converts, not analysed here), who wanted more participation. It was in fact women's greater participation in the prayers that made some men in the community demand the mounting of the mechitza even in a place where it had never been before.

The influence of the surrounding society - and its gender ideals - was seen in my informants' understanding of themselves as both Finns and Jews. Their Finnishness was accentuated in international Jewish contexts, probably especially Orthodox ones. On the one hand, being a Finnish Jewish woman was experienced as a distinctive and positive identity. On the other hand, the growing sense of conflict between one's Finnishness and Jewishness was not expressed in gendered terms but rather as a result of Finnish 


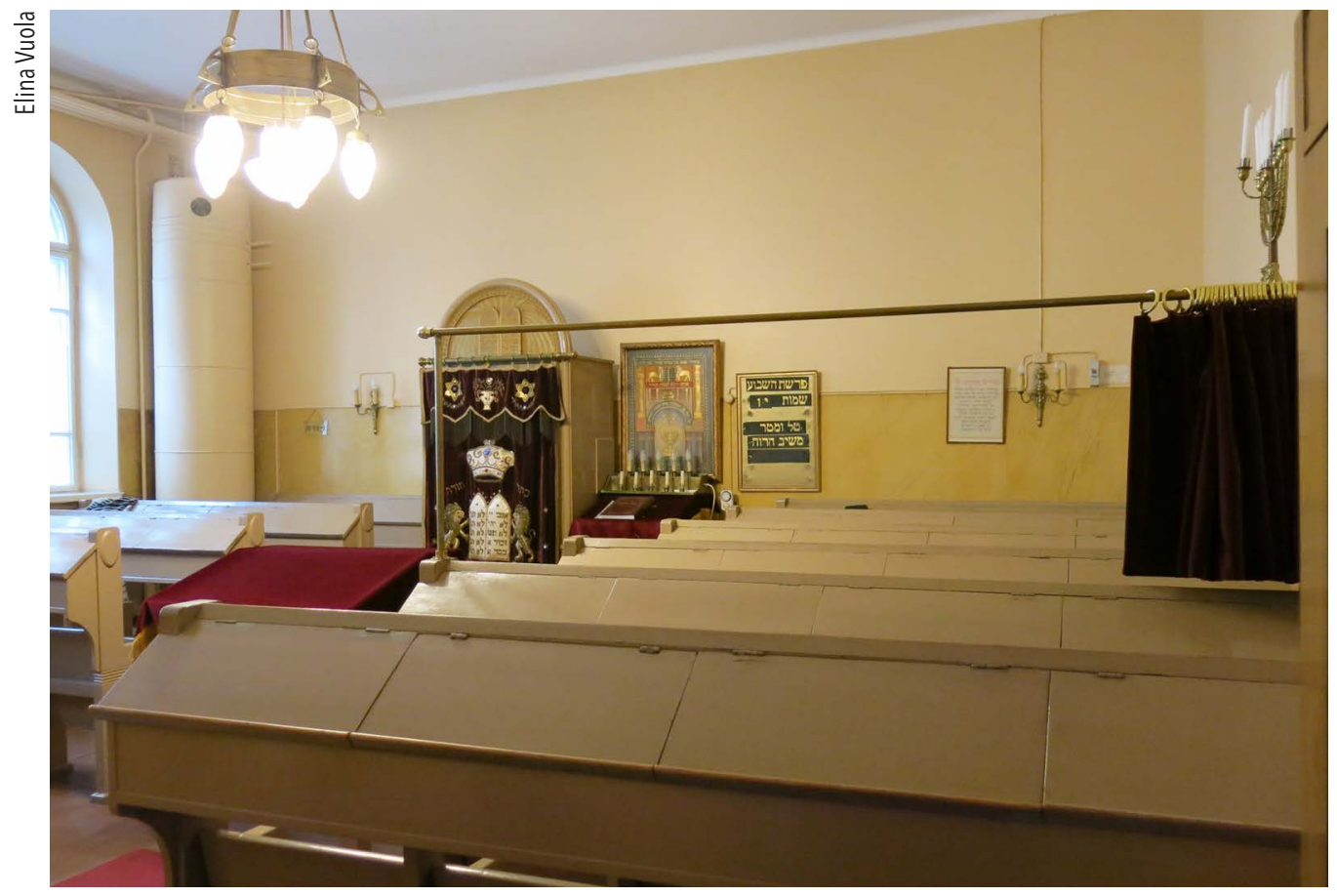

The Turku community prayer room.

people's stereotypes and lack of knowledge about Judaism and, more recently, of growing antisemitism and the tendency to blame all Jews for Israel's policies.

The Finnish Jewish community is unique when analysed from a gender perspective. Its 'Finnish Orthodoxy' is an outcome of a long history of integration into the genderequality norms and ideals of the surrounding society as well as the high level of intermarriage. Those gendered practices such as separate spaces in the synagogue were by and large accepted and not considered a big problem. Women did not want to 'shake the small boat' on stormy waters by demanding drastic changes, because they did not feel oppressed and limited as women. The male power hierarchy in the community was not seen as something unique to the Jewish community but as a more general problem in all spheres of society. The women expressed how some practices could be changed to enhance women's greater participation and representation - without violating Jewish law.

Consideration of the Finnish Jewish community, especially when analysed from an intersectional gender perspective, makes it clear that there is no single Orthodox Judaism which is guided by a strict observance of the halakhah and its normative interpretations. Rather, the influence of the cultural context, specific history and the gender norms of the surrounding society affect all Jewish communities to some extent.

The uniqueness of the Finnish community is in its creative tension between its self-identification as (Modern) Orthodox and its non-observance of many important aspects of Orthodox Judaism, especially in issues related to gender (intermarriage, niddab). This does not mean that the community does not have the right to its current self-identification, which in the end keeps the small minority alive in a society where it 
is practically impossible to live an Orthodox life such as in Israel, London or New York. Finnish Jewish women are important 'balance keepers' in this situation through their deep commitment to the tradition and Jewish life at the same time as they define the borders of Orthodox Judaism for themselves. In practice, this means that the gender-equality norms of secular society are taken for granted and even cherished. This results in somewhat separate norms in the secular and religious spheres, which were accepted to avoid too dramatic a change in the small community.

Many informants openly questioned and challenged male hierarchy and power use. Even more, practices considered irrelevant were simply ignored. Some women questioned androcentric teachings by contrasting them with a view of Judaism as supportive of gender equality and a view of God as beyond gender. This is a similar tactic to that used by women in other religious traditions: their critique of androcentrism is based on an alternative interpretation of one's religion, which sees sexist practices as results of male power, not religion as such. Judaism as religion, just like any religious tradition, can be experienced by women as both a structure of patriarchal power to be questioned and as a source of empowerment. In fact, through the ethnographic method - when ordinary women are interviewed - this double view often comes to the fore. ${ }^{15}$ It is important to hear and analyse these views in greater depth in the context of Judaism, since they correspond with Jewish feminist theology, an important but often ignored body of scholarly work.

15 I have also interviewed Catholic Costa Rican and Orthodox Christian Finnish women (see Vuola 201 9, forthcoming).
Elina Vuola ThD is Professor of Global Christianity and Dialogue of Religions at the Faculty of Theology, University of Helsinki, Finland. Her research has covered feminist theology, liberation theology, Latin American gender studies and religious minorities in Finland from the perspective of body and gender. She has been a visiting scholar at the Departamento Ecuménico de Investicaciones in San José, Costa Rica (1991-3, 1999-2000) as well as at the Women's Studies in Religion Program at the Harvard Divinity School (2002-3) and the Crown Family Center for Jewish and Israel Studies at Northwestern University in the United States.

\section{References}

Adler, Rachel, 1998. Engendering Judaism: An Inclusive Theology and Ethics (Philadelphia, The Jewish Publication Society)

Baskin, Judith R., I998. Jerwish Women in Historical Perspective, 2nd edn (Detroit, Wayne State University Press)

2015 . 'Women, gender, and Judaism', The Bloomsbury Companion to Jewish Studies, ed. Dean P. Bell (London, Bloomsbury), pp. 229-50

Bell, Dean Phillip, 20I 5. 'Introduction', The Bloomsbury Companion to Jewish Studies, ed. Dean P. Bell (London, Bloomsbury), pp. I-2 I

Berman, Rabbi Shaul J., 200I. 'The ideology of Modern Orthodoxy', Sh'ma, February, pp. I-2

Biale, Rachel, I 995. Women and Jewish Law: The Essential Texts, Their History, and Their Relevance for Today, 2nd edn (New York, Schocken Books)

Brah, Avtar, and Ann Phoenix, 2004. 'Ain't I a woman? Revisiting intersectionality', Journal of International Women's Studies, 5(3), pp. $75^{-86}$

Braude, Ann, 2004. 'Introduction', Transforming the Faiths of Our Fathers: Women Who Changed American Religion, ed. Ann Braude (New York, Palgrave Macmillan), pp. I-I I

Brettschneider, Maria, 2016. Jewish Feminism and Intersectionality (Albany, State University of New York Press) 
Castelli, Elizabeth, 200r. 'Women, gender, religion: troubling categories and transforming knowledge', Women, Gender, Religion: A Reader, ed. Elizabeth Castelli (New York, Palgrave Macmillan), pp. 3-25

Christ, Carol, and Judith Plaskow (eds), I 979. Womanspirit Rising: A Feminist Reader in Religion (San Francisco, Harper \& Row)

Crenshaw, Kimberlé, r 989. 'Demarginalizing the intersection of race and sex: a black feminist critique of antidiscrimination doctrine, feminist theory and antiracist politics', University of Chicago Legal Forum, pp. 139-67

Czimbalmos, Mercédesz, 20r 6. 'How do they Jew? Identity and Religiosity in the Jewish Community of Helsinki', unpublished MA thesis, University of Helsinki, Faculty of Arts

Dahl, Izabela A., and Malin Thor Tureby, 2009. 'Oral history, constructions and deconstructions of narratives: intersections of class, gender, locality, nation and religion in narratives from a Jewish woman in Sweden', Enquire, 3, pp. I-24

Davis, Kathy, 2008. 'Intersectionality as buzzword: a sociology of science perspective on what makes feminist theory successful', Feminist Theory, 9(I), pp. 67-85

Dencik, Lars, I 993. 'Hemma i hemslösheten', Judisk identitet, ed. Jackie Jakubowski (Stockholm, Natur och kultur), pp. 48-70

Eck, Diana L., and Devaki Jain (eds), I 986. Speaking of Faith: Cross-Cultural Perspectives on Women, Religion, and Social Change (London, The Women's Press)

Egnell, Helene, 2006. Other Voices: A Study of Christian Feminist Approaches to Religious Pluralism East and West (Uppsala, Swedish Institute of Mission Research)

Fader, Ayala, 2009. Mitzvah Girls: Bringing up the Next Generation of Hasidic Jerws in Brooklyn (Princeton University Press)

FRA 201 8. Experiences and Perceptions of Antisemitism: Second Survey on Discrimination and Hate Crime agains Jews in the EU (European Union Agency for Fundamental Rights), $<$ https://fra.europa.eu/sites/default/files/ fra_uploads/fra-201 8-experiences-andperceptions-of-antisemitism-survey_en.pdf>

Goldstein, Elyse (ed.), 2009. New Jewish Feminism: Probing the Past, Forging the Future (Woodstock, Jewish Lights Publishing)

Greenebaum, Jessica, I 999. 'Placing Jewish women into the intersectionality of race, class and gender', Race, Gender E Class, 6(4), pp. $4 \mathrm{I}-6 \mathrm{O}$

Greenspahn, Frederick E. (ed.), 2009. Women and Judaism: Nerw Insights and Scholarship (New York University Press)

Halkes, Catharina, and Daan Buddingh (eds), I 979. Wenn Frauen ans Wort kommen. Stimmen zur feministischen Theologie (Berlin, Gelnhausen)

Hartman, Tova, 2007. Feminism Encounters Traditional Judaism: Resistance and Accommodation (Waltham, Brandeis University Press)

Heschel, Susannah (ed.), 1983. On Being a Jewish Feminist: A Reader (New York, Schocken)

Labovitz, Gail, 20 I r. 'Engendering halakhah: Rachel Adler's Berit Ahuvim and the quest to create a feminist halakhic praxis', Jewish Cultural Studies, vol. 3, Revisioning Ritual Jewish Traditions in Transition, ed. Simon J. Bronner (Portland, The Littman Library of Jewish Civilization), pp. I65-89

Lahav, Hagar, 201 5 . 'Post-secular Jewish feminist theology? The view from Israel', Journal of Modern Jerwish Studies, I4(3), pp. 355-72

Larsson, Julia, 20 I4. 'Juutalaisuus on sitä, että lukee ensimmäisenä lehdestä juutalaisia koskevat uutiset. Suomen juutalaisten nuorten aikuisten käsityksiä omasta juutalaisuudestaan', unpublished MA thesis, University of Helsinki, Faculty of Educational Sciences

Ludvig, Alice, 2006. 'Differences between women? Intersecting voices in a female narrative', European Journal of Women's Studies, I3 (3), pp. $245-58$

Lykke, Nina, 2003. 'Intersektionalitet - ett användbart begrepp för genusforskningen', Kvinnovetenskaplig tidskrift, I, pp. 47-56

2005. 'Nya perspektiv på intersektionalitet. Problem och möjligheter', Kvinnovetenskaplig tidskrift, 2-3, pp. 7-I 7

Mahmood, Saba, 2005. Politics of Piety: The Islamic Revival and the Feminist Subject (Princeton University Press)

McCall, Leslie, 2005. 'The complexity of intersectionality', Signs, 3 (30), pp. I 77 I-1 800

Morgenshtern, Marina, and Shoshana Pollack, 2016. 'Stories of (be)longing to the center: race, class and ethnicity in FSU Jewish immigrant experiences', The International Journal of Diversity in Organizations, Communities and Nations: Annual Review, I6, pp. 19-35

Nash, Jennifer C., 2008. 'Re-thinking intersectionality', Feminist Review, 89, pp. I-I 5 
Neriya-Ben Shahar, Rivka, 201 8. 'The Amen Meal: Jewish women experience lived religion through a new ritual', Nashim: A Journal of Jerwish Women's Studies and Gender Issues, 33 , pp. $55^{8-76}$

Nylund Skog, Susanne, 2008. 'In Persia I was called the Blond': an attempt to analyse how a Jewess practices whiteness', Thinking with Beverley Skeggs, ed. Annika Olsson (Stockholm, Centre for Gender Studies), pp. 65-73

Pankowski, Rafal, 20 19. 'What is antisemitism?', unpublished paper at the seminar on antisemitism and Islamophopia - what they are and how they are expressed in Finland. Helsinki, 27 February 201 9, organised by the Ministry of the Interior, Jewish Community of Helsinki and Suomen Muslimiverkosto

Peskowitz, Miriam, and Laura Levitt (eds), r 997. Judaism since Gender (New York, Routledge)

Plaskow, Judith, 1990. Standing Again at Sinai: Judaism from a Feminist Perspective (New York, Harper Collins Publishers)

Raphael, Melissa, 2003. The Female Face of God in Auschwitz: A Jewish Feminist Theology of the Holocaust (London, Routledge)

Ross, Tamar, 2004. Expanding the Palace of Torah: Orthodoxy and Feminism (Waltham, Brandeis University Press)

Ruether, Rosemary R., I 972 . Liberation Theology: Human Hope Confronts Christian History and American Power (New York, Paulist Press)

- 982. Disputed Questions: On Being a Christian (Nashville, Abingdon)

Shaul, Daniel, 20 I 7. 'Ympärileikkaus juutalaisuudessa. Juutalaisen identiteetin kulmakivi?' Unpublished MA thesis, University of Helsinki, Faculty of Educational Sciences

Sztokman, Elana Maryles, 20I I. The Men's Section. Orthodox Jewish Men in an Egalitarian World (Waltham, Brandeis University Press)

Taubes, Shuli, 2018. 'The delicate power of Modern Orthodox Judaism', Harvard Divinity Bulletin, 46(3-4), <https://bulletin. hds.harvard.edu/articles/autumnwinter 20 I $8 /$ delicate-power-modern-orthodox-judaism> (accessed 10.3.2019)

Vuola, Elina, 201 2. 'Intersectionality in Latin America? The possibilities of intersectional analysis in Latin American studies and study of religion', Bodies and Borders in Latin America, ed. Silje Lundgren, Thaïs MachadoBorges and Cecilia Widmark (Stockholm University and University of Gothenburg), pp. I 3 I -5 I
2015.'Unohdettu ero?

Intersektionaalisuus, naiset ja uskonto', Uskonnon ja sukupuolen risteyksiä, ed. Johanna Ahonen and Elina Vuola (Helsinki, SKS), pp. $32-54$

2016. 'Feminist theology, religious studies and gender studies: mutual challenges', Contemporary Encounters in Gender and Religion: European Perspectives, ed. Lena Gemzöe, Marja-Liisa Keinänen and Avril Maddrell (New York, Palgrave MacMillan), pp. 307-34

2017. 'Religion, intersectionality, and epistemic habits of academic feminism: perspectives from global feminist theology', Feminist Encounters: A Journal of Critical Studies in Culture and Politics, I(I), pp. I-I5, $<$ https://doi.org/I0.20897/femenc.20I704> 2019 (forthcoming). The Virgin Mary across Cultures: Devotion among Costa Rican Catholic and Finnish Orthodox Women (London, Routledge)

Yuval-Davis, Nira, 2006. 'Intersectionality and feminist politics', European Journal of Women's Studies, I3(3), pp. 193-209 